Check for updates

Cite this: Phys. Chem. Chem. Phys., 2018, 20, 16256

Received 9th May 2018 Accepted 17th May 2018

DOI: $10.1039 / \mathrm{c} 8 \mathrm{cp} 02962 \mathrm{~h}$

rsc.li/pccp

\title{
Aluminum and Fenton reaction: how can the reaction be modulated by speciation? A computational study using citrate as a test case
}

\author{
Jon I. Mujika, (D) ${ }^{\text {a }}$ Gabriele Dalla Torre (D) ${ }^{\text {ab }}$ and Xabier Lopez ${ }^{\text {a }}$
}

The pro-oxidant ability of aluminum is behind many of the potential toxic effects of this exogenous element in the human organism. Although the overall process is still far from being understood at the molecular level, the well known ability of aluminum to promote the Fenton reaction is mediated through the formation of stable aluminum-superoxide radical complexes. However, the properties of metal complexes are highly influenced by the speciation of the metal. In this paper, we investigate the effect that speciation could have on the pro-oxidant activity of aluminum. We choose citrate as a test case, because it is the main low-molecular-mass chelator of aluminum in blood serum, forming very stable aluminum-citrate complexes. The influence of citrate in the interaction of aluminum with the superoxide radical is investigated, determining how the formation of aluminum-citrate complexes affects the promotion of the Fenton reaction. The results indicate that citrate increases the stability of the aluminum-superoxide complexes through the formation of ternary compounds, and that the Fenton reaction is even more favorable when aluminum is chelated to citrate. Nevertheless, our results demonstrate that overall, citrate may prevent the pro-oxidant activity of aluminum: on one hand, in an excess of citrate, the formation of 1:2 aluminum-citrate complexes is expected. On the other hand, the chelation of iron by citrate makes the reduction of iron thermodynamically unfavorable. In summary, the results suggest that citrate can have both a promotion and protective role, depending on subtle factors, such as initial concentration, non-equilibrium behavior and the exchange rate of ligands in the first shell of the metals.

\section{Introduction}

Aluminum is the third most abundant element in the Earth's crust, but complex geochemical cycles prevent its solubilization from the lithosphere, ${ }^{1-3}$ keeping this abundant metal out of essential biological cycles. Nevertheless, in the last century, aluminum has been extracted on a massive scale from the soil due to its favorable properties (easy to manipulate, cheap and good physicochemical properties) and a myriad of applications (food additives, pharmaceuticals, Al-containers, etc.). As a consequence, aluminum is nowadays present in the biosphere, and humans are highly exposed to this metal. ${ }^{4,5}$ Unfortunately, this is not without consequences, and this exposure to aluminum has been linked to various diseases, ${ }^{6-9}$ starting from early evidence of dialysis encephalopathy or osteodistrophy in patients with renal

\footnotetext{
${ }^{a}$ Kimika Fakultatea, Euskal Herriko Unibertsitatea UPV/EHU, and Donostia International Physics Center (DIPC), P.K. 1072, 20080 Donostia, Euskadi, Spain. E-mail:xabier.lopez@ehu.es

${ }^{b}$ UCBIO/REQUIMTE, Departamento de Química e Bioquímica,

Faculdade de Ciências, Universidade do Porto, s/n, Porto, Portugal
}

failure under dialysis treatment, ${ }^{10,11}$ to more recent evidence linking aluminum to several neurodegenerative diseases. ${ }^{6,8}$ The high charge and small volume of aluminum make this metal a strong Lewis acid, with high affinity towards oxygen-containing and negatively-charged functional groups, such as phosphates or carboxylic groups. Therefore, aluminum has the potential ability to form strong interactions with important biomolecules such as proteins, phospholipids, ATP, NADH, RNA, DNA, etc. ${ }^{12}$

The pro-oxidant ability of aluminum is one of the main deleterious effects of aluminum, observed in both in vitro and in vivo experiments. ${ }^{13,14}$ This is a feature not expected for an element without a redox capability. ${ }^{15,16}$ It was first hypothesized $^{13,15}$ that this pro-oxidant activity was due to the formation of a strong aluminum-superoxide complex, which leads to an increase of the lifetime of the superoxide radical species. In fact, Fukuzumi et al. reported a linear relationship between the strength of the metal-superoxide interaction and the oxidant activity of the metal. ${ }^{17-19}$ Based on this hypothesis, we demonstrated ${ }^{20}$ the possibility of the formation of an aluminum-superoxide complex in solution, departing from various aluminum hydrolytic species. Further calculations confirmed 

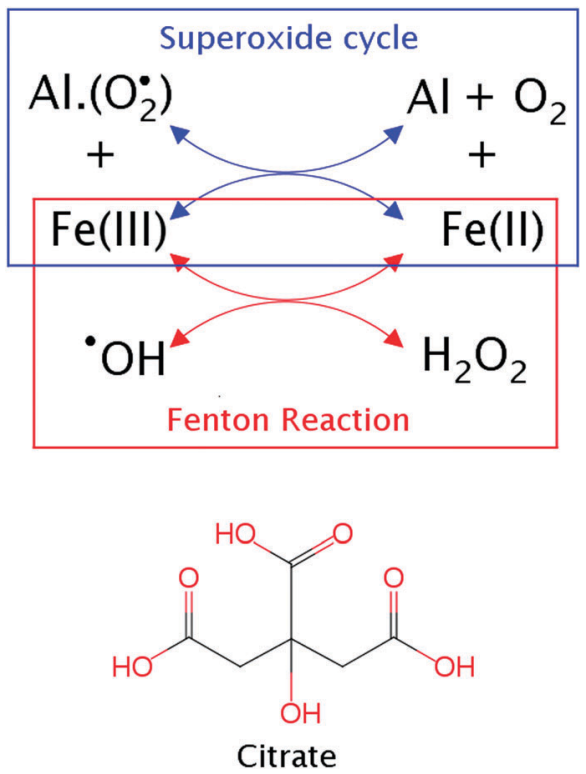

Fig. 1 Above, a possible route for the pro-oxidant activity of aluminum by the promotion of the Fenton reaction. Below, the molecular structure of citrate.

that these aluminum-superoxide complexes may increase oxidative stress in biological environments by acting as promoting agents of the Fenton reaction ${ }^{21}$ (see Fig. 1).

However, most of the aluminum present in the human organism is not free in solution, but forms stable complexes with low and high molecular mass biomolecules, and this could have a strong effect on the pro-oxidant activity of aluminum. Many attempts have been made to identify the molecules interacting with aluminum in biological systems. ${ }^{22-25}$ However, due to the complex chemistry of aluminum, its low total concentration, and the high risk of sample-contamination, the study of the speciation of aluminum is a complex task. ${ }^{24}$ Nowadays, it is accepted that $90 \%$ of the aluminum found in the blood serum is bound to serum transferrin protein, while citrate is the main low molecular weight chelator. ${ }^{26}$ Further, citrate has been identified as the main chelator of aluminum in brain extracellular fluid. ${ }^{6}$ This behavior is not surprising as the molecular composition of citrate with three carboxylic groups and an alcohol group (shown in Fig. 1) provides high affinity towards Al(III). Interestingly, in previous studies, it was demonstrated that the formation of ternary complexes with citrate can enable a protective role with respect to some of the deleterious effects of aluminum. ${ }^{27,28}$

In the present study, our goal is to analyze how the interaction with citrate could alter (i) the possibility of the formation of aluminum-superoxide complexes and (ii) the possibility of reducing $\mathrm{Fe}(\mathrm{III})$ to $\mathrm{Fe}(\mathrm{II})$, promoting the Fenton reaction. To do so, we evaluate the binding energies of $\mathrm{Al}(\mathrm{III})$ to superoxide and citrate, and the reaction free energy of iron reduction from $\mathrm{Fe}$ (III) to $\mathrm{Fe}$ (II) in the presence of aluminum-superoxide radical binary species and aluminum-citrate-superoxide ternary species. To be consistent, we also consider the changes in the corresponding energies when citrate is bound to iron. The study describes a complex scenario that ultimately depends on the relative concentrations of each species. However, the results point in general to the protective role of citrate with respect to the pro-oxidant ability of aluminum, especially in high-citrate concentration regimes.

\section{Methodology}

All geometries were optimized in solution at two levels of theory using the B3LYP functional ${ }^{29-32}$ and $6-31++g(d, p)$ basis set: B3LYP/6-31++g(d,p) and B3LYP-D3(BJ)/6-31++g(d,p). In the latter level of theory, the D3 version of Grimme's dispersion with Becke-Johnson damping is included. ${ }^{33}$ To confirm that the optimized structures were real minima on the potential energy surfaces, frequency calculations were carried out at the same level of theory. All structures showed positive force constants for all the normal modes of vibration. The frequencies were then used to evaluate the zero-point vibrational energy (ZPVE) and the thermal $(T=298 \mathrm{~K})$ vibrational corrections to the enthalpies and Gibbs free energies within the harmonic oscillator approximation. To calculate the entropy, the different contributions to the partition function were evaluated using the standard statistical mechanics expressions in the canonical ensemble and the harmonic oscillator and rigid rotor approximation. The solvent effect was introduced by using the self-consistent reaction field (SCRF) method with the polarized continuum model (PCM), using the integral equation formalism variant (IEFPCM). ${ }^{34}$

Once the geometries were optimized at the two levels of theory stated above, the electronic energies were refined using the larger basis set $6-311++g(3 \mathrm{df}, 2 \mathrm{p})$ by two distinct single-point energy calculations: (a) using the same functional as that in the geometry optimization or (b) using the wB97XD hybrid functional with the dispersion correction included in it. ${ }^{35}$ Thus, for each reaction, a set of four different energies are presented (energy evaluation//geometry optimization): (i) B3LYP/TZ// $\mathrm{B} 3 \mathrm{LYP} / \mathrm{DZ}\left(\Delta G_{\mathrm{aq}}^{\mathrm{B} 3 \mathrm{LYP}}\right)$, (ii) ${ }_{\mathrm{wB}} \mathrm{XXD} / \mathrm{TZ} / / \mathrm{B} 3 \mathrm{LYP} / \mathrm{DZ}\left(\Delta G_{\mathrm{aq}}^{\mathrm{B} 3, \mathrm{wB} 97}\right)$, (iii) B3LYP-D3/TZ//B3LYP-D3/DZ $\left(\Delta G_{\mathrm{aq}}^{\mathrm{B} 3-\mathrm{D} 3}\right)$, and (iv) wB97XD/ $\mathrm{TZ} / / \mathrm{B} 3 \mathrm{LYP}-\mathrm{D} 3 / \mathrm{DZ}\left(\Delta G_{\mathrm{aq}}^{\mathrm{B} 3-\mathrm{D} 3, \mathrm{wB} 97}\right)$, where $\mathrm{TZ}=6-311++\mathrm{g}(3 \mathrm{df}, 2 \mathrm{p})$ and $\mathrm{DZ}=6-31++\mathrm{g}(\mathrm{d}, \mathrm{p})$. All these calculations were carried out using the Gaussian $09^{36}$ and $16^{37}$ packages.

As in our previous study, we considered different hydrated models for the Al-Citr complex, where different numbers of water and hydroxide molecules were included. Departing from each of these models, the substitution reaction of a water molecule (eqn (1)) or a hydroxide (eqn (2)) by the superoxide to form an $\mathrm{Al}-\mathrm{Citr}-\mathrm{O}_{2} \bullet$ complex was studied:

$$
\begin{gathered}
\quad\left[\operatorname{AlCitr}\left(\mathrm{H}_{2} \mathrm{O}\right)_{n}(\mathrm{OH})_{m}\right]_{(\mathrm{aq})}{ }^{-(1+m)}+\left[\mathrm{O}_{2}^{\bullet}\left(\mathrm{H}_{2} \mathrm{O}\right)_{2}\right]_{(\mathrm{aq})}{ }^{-} \rightarrow \\
{\left[\operatorname{AlCitr}\left(\mathrm{H}_{2} \mathrm{O}\right)_{n-1}(\mathrm{OH})_{m} \mathrm{O}_{2}^{\bullet}\right]_{(\mathrm{aq})}-(2+m)+\left[\mathrm{H}_{2} \mathrm{O}\left(\mathrm{H}_{2} \mathrm{O}\right)_{2}\right]_{(\mathrm{aq})}} \\
{\left[\operatorname{AlCitr}\left(\mathrm{H}_{2} \mathrm{O}\right)_{n}(\mathrm{OH})_{m}\right]_{(\mathrm{aq})}{ }^{-(1+m)}+\left[\mathrm{O}_{2}^{\bullet}\left(\mathrm{H}_{2} \mathrm{O}\right)_{2}\right]_{(\mathrm{aq})}{ }^{-} \rightarrow} \\
{\left[\operatorname{AlCitr}\left(\mathrm{H}_{2} \mathrm{O}\right)_{n}(\mathrm{OH})_{m-1} \mathrm{O}_{2}\right]_{(\mathrm{aq})}^{-(1+m)}+\left[\mathrm{OH}\left(\mathrm{H}_{2} \mathrm{O}\right)_{2}\right]_{(\mathrm{aq})}^{-}}
\end{gathered}
$$


where $n$ and $m$ are the number of water and hydroxide molecules, respectively. Note that in accordance with some test calculations carried out previously, ${ }^{20}$ the small ligands (superoxide, water molecule and hydroxide) were micro-solvated with two explicit water molecules to improve their solvation energy. Moreover, citrate was considered completely deprotonated with a net charge of -4 (see below).

The free energies in solution corresponding to these two reactions are calculated as:

$$
\begin{aligned}
\Delta G_{\mathrm{aq}}= & G_{\mathrm{aq}}\left(\operatorname{AlCitr}\left(\mathrm{H}_{2} \mathrm{O}\right)_{n-1}(\mathrm{OH})_{m} \mathrm{O}_{2}^{\bullet}\right)+G_{\mathrm{aq}}\left(\mathrm{H}_{2} \mathrm{O}\left(\mathrm{H}_{2} \mathrm{O}\right)_{2}\right) \\
& -G_{\mathrm{aq}}\left(\operatorname{AlCitr}\left(\mathrm{H}_{2} \mathrm{O}\right)_{n}(\mathrm{OH})_{m}\right)-G_{\mathrm{aq}}\left(\mathrm{O}_{2}^{\bullet}\left(\mathrm{H}_{2} \mathrm{O}\right)_{2}\right)
\end{aligned}
$$

or

$$
\begin{aligned}
\Delta G_{\mathrm{aq}}= & G_{\mathrm{aq}}\left(\mathrm{Al} \cdot \operatorname{Citr} \cdot\left(\mathrm{H}_{2} \mathrm{O}\right)_{n} \cdot(\mathrm{OH})_{m-1} \cdot \mathrm{O}_{2}^{\bullet}\right)+G_{\mathrm{aq}}\left(\mathrm{OH} \cdot\left(\mathrm{H}_{2} \mathrm{O}\right)_{2}\right) \\
& -G_{\mathrm{aq}}\left(\mathrm{Al} \cdot \operatorname{Citr} \cdot\left(\mathrm{H}_{2} \mathrm{O}\right)_{n} \cdot(\mathrm{OH})_{m}\right)-G_{\mathrm{aq}}\left(\mathrm{O}_{2} \cdot\left(\mathrm{H}_{2} \mathrm{O}\right)_{2}\right)
\end{aligned}
$$

The $\Delta G_{\text {aq }}$ values were computed at the four levels of theory described above. All these values are presented in Tables 1-3, but since the overall trends are maintained, only the $\Delta G_{\mathrm{aq}}^{\mathrm{B} 3-\mathrm{D} 3}$ values are discussed throughout the body text.

For all the aluminum containing structures, we also calculated delocalization indices (DIs). These are a measure of the covariance between the population of two atoms A and B and, consequently, a measure of the number of electrons simultaneously fluctuating between these atoms, ${ }^{38,39}$

$$
\delta(\mathrm{A}, \mathrm{B})=\int_{\mathrm{A}} \int_{\mathrm{B}} d 1 d 2 \rho_{\mathrm{xc}}(1,2)=\operatorname{cov}\left(N_{\mathrm{A}}, N_{\mathrm{B}}\right)
$$

where $\rho_{\mathrm{xc}}(1,2)$ is the exchange-correlation density. ${ }^{40}$ It can be taken as the number of electron pairs shared between atoms $\mathrm{A}$ and $\mathrm{B}$, i.e., the bond order. ${ }^{41}$ The AIMAll v11.08.23 program $^{42}$ was used to carry out the QTAIM analysis (which includes the characterization of DIs) on the previously optimized structures. Wavefunctions for QTAIM analysis were obtained at the B3LYP/6-311++g(3df,2p) level of theory using the IEFPCM solvation model.

\section{Results and discussion}

\section{Incorporation of the $\mathrm{O}_{2}$ superoxide radical}

In our previous work, we investigated the incorporation of $\mathrm{O}_{2}{ }^{\bullet-}$ into the first coordination shell of aluminum hydrolytic species. $^{20}$ In particular, the displacement of either a water molecule or a hydroxide from the first coordination shell was analyzed by evaluating the $\Delta G_{\mathrm{aq}}$ of one of the next reactions:

$$
\left[\mathrm{Al}\left(\mathrm{H}_{2} \mathrm{O}\right)_{n}(\mathrm{OH})_{m}\right]^{3-m}+\mathrm{O}_{2}^{\bullet-} \rightarrow\left[\mathrm{Al}\left(\mathrm{H}_{2} \mathrm{O}\right)_{n-1}(\mathrm{OH})_{m} \mathrm{O}_{2}^{\bullet}\right]^{2-m}+\mathrm{H}_{2} \mathrm{O}
$$

$\left[\mathrm{Al}\left(\mathrm{H}_{2} \mathrm{O}\right)_{n}(\mathrm{OH})_{m}\right]^{3-m}+\mathrm{O}_{2}^{\bullet-} \rightarrow\left[\mathrm{Al}\left(\mathrm{H}_{2} \mathrm{O}\right)_{n}(\mathrm{OH})_{m-1} \mathrm{O}_{2}^{\bullet}\right]^{3-m}+\mathrm{OH}^{-}$

where eqn (5) implies the substitution of a water molecule by the superoxide anion, and eqn (6) implies the substitution of a hydroxide. The subscripts $n$ and $m$ refer to the number of water molecules and hydroxides present in the complexes. Note that these reactions are analogous to reactions (1) and (2), but without the presence of citrate. The results clearly indicated that the substitution of a water molecule by the superoxide radical anion was energetically favorable (data shown in Table 1), whereas the substitution of a hydroxide was unfavorable in all cases. Besides, we concluded that the charge of the complex is a contributing factor, as the larger the number of negatively charged hydroxides in the first coordination shell, the less negative the $\Delta G_{\text {aq }}$ value for the displacement of water molecules by the superoxide radical.

Now, we will analyze whether aluminum can form a stable complex with the superoxide radical anion in the presence of citrate, a ligand composed of three carboxylic groups and an alcohol group (see Fig. 1). Previously, $\mathrm{p} K_{\mathrm{a}}$ values of $-14.5,-8.0$, 0.6 and 3.6 were computed for the four titratable groups of an aluminum-bound citrate molecule, ${ }^{43}$ which are in accordance with the two known experimental values, the two highest ones: 2.3 and 3.6. ${ }^{23}$ Therefore, we assume that under physiological conditions, the $\mathrm{Al}(\mathrm{III})$-bound citrate is fully deprotonated. Note that the $\mathrm{p} K_{\mathrm{a}}$ values of free citrate in solution $(2.9,4.3$, 5.6 and 11.6/14.4) suggest a different protonation state, with the alcohol group protonated. ${ }^{43}$ Different coordination modes between citrate and $\mathrm{Al}(\mathrm{III})$ were also compared, ${ }^{43}$ concluding that citrate interacts in a tridentate manner with aluminum.

Different solvation models were considered for the aluminum-citrate complexes, varying in the number of water/ hydroxide molecules. In all of them, aluminum presents an octahedral arrangement, with three of the six first coordination shell positions occupied by citrate, and three of them available for water or hydroxide molecules. All possible combinations were taken into account, giving rise to a total of four structures

Table 1 Reaction free energies in solution (in $\mathrm{kcal} \mathrm{mol}^{-1}$ ) evaluated for the substitution of a water molecule (eqn (5)) or hydroxide (eqn (6)) located in the aluminum first coordination shell of aluminum hydrolytic species by the $\mathrm{O}_{2}{ }^{\bullet}$ superoxide radical computed at the levels of theory described in the

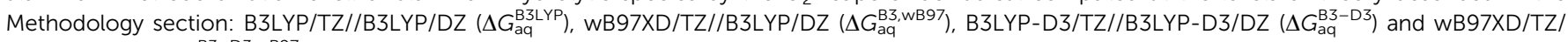
B3LYP-D3/DZ $\left(\Delta G_{\mathrm{aq}}^{\mathrm{B} 3-\mathrm{D} 3, \mathrm{wB} 97)}\right.$

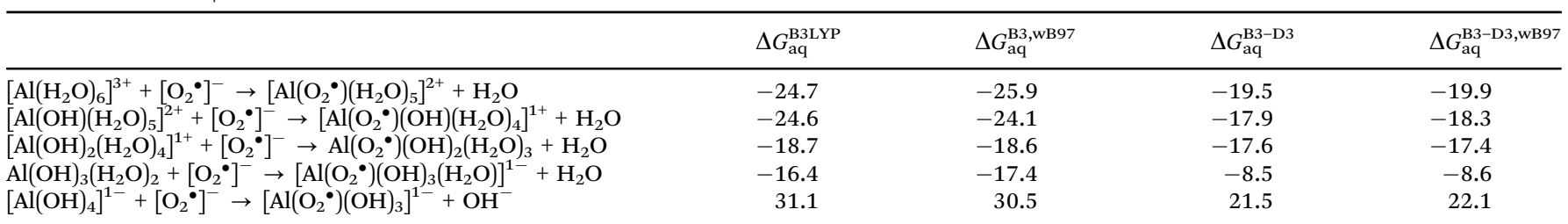


Table 2 Reaction free energies in solution (in kcal mol${ }^{-1}$ ) evaluated for the substitution of a water molecule (eqn (1)) or a hydroxide ion (eqn (2)) located in the aluminum first coordination shell of $\mathrm{Al}-\mathrm{Citr}$ complexes by the $\mathrm{O}_{2}{ }^{\bullet}$ superoxide radical (structures shown in Fig. 2). $\Delta G_{\text {aq }}$ values computed at the

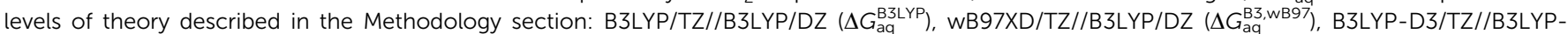
$\mathrm{D} 3 / \mathrm{DZ}\left(\Delta G_{\mathrm{aq}}^{\mathrm{B} 3-\mathrm{D} 3}\right)$ and $\mathrm{wB} 97 \mathrm{XD} / \mathrm{TZ} / / \mathrm{B} 3 L Y \mathrm{~L}-\mathrm{D} 3 / \mathrm{DZ}\left(\Delta G_{\mathrm{aq}}^{\mathrm{B} 3-\mathrm{D} 3, \mathrm{wB} 97)}\right.$

\begin{tabular}{|c|c|c|c|c|}
\hline & $\Delta G_{\mathrm{aq}}^{\mathrm{B} 3 \mathrm{LYP}}$ & $\Delta G_{\mathrm{aq}}^{\mathrm{B3}, \mathrm{wB} 97}$ & $\Delta G_{\mathrm{aq}}^{\mathrm{B3}-\mathrm{D} 3}$ & $\Delta G_{\mathrm{aq}}^{\mathrm{B} 3-\mathrm{D} 3, \mathrm{wB} 97}$ \\
\hline $\begin{array}{l}{\left[\operatorname{AlCitr}\left(\mathrm{H}_{2} \mathrm{O}\right)_{2}(\mathrm{OH})\left(\mathrm{H}_{2} \mathrm{O}\right)_{10}\right]^{2-}+\left[\mathrm{O}_{2}^{\bullet}\right]^{-} \rightarrow\left[\operatorname{AlCitr}\left(\mathrm{H}_{2} \mathrm{O}\right)_{2}\left(\mathrm{O}_{2}^{\bullet}\right)\left(\mathrm{H}_{2} \mathrm{O}\right)_{10}\right]^{2-}+\mathrm{OH}^{-}} \\
{\left[\operatorname{AlCitr}\left(\mathrm{H}_{2} \mathrm{O}\right)(\mathrm{OH})_{2}\left(\mathrm{H}_{2} \mathrm{O}\right)_{10}\right]^{3-}+\left[\mathrm{O}_{2}\right]^{-} \rightarrow\left[\operatorname{AlCitr}\left(\mathrm{H}_{2} \mathrm{O}\right)(\mathrm{OH})\left(\mathrm{O}_{2}{ }^{-}\right)\left(\mathrm{H}_{2} \mathrm{O}\right)_{10}\right]^{3-}+\mathrm{OH}^{-}} \\
\left.\left[\operatorname{AlCitr}(\mathrm{OH})_{3}\left(\mathrm{H}_{2} \mathrm{O}\right)_{10}\right]^{4-}+\left[\mathrm{O}_{2}\right]^{-}\right]^{-} \rightarrow\left[\operatorname{AlCitr}(\mathrm{OH})_{2}\left(\mathrm{O}_{2} \cdot\left(\mathrm{H}_{2} \mathrm{O}\right)_{10}\right]^{4-}+\mathrm{OH}^{-}\right.\end{array}$ & $\begin{array}{r}15.5 \\
16.6 \\
3.2\end{array}$ & $\begin{array}{r}16.3 \\
16.1 \\
5.2\end{array}$ & $\begin{array}{r}16.5 \\
14.0 \\
4.1\end{array}$ & $\begin{array}{r}17.5 \\
14.8 \\
5.2\end{array}$ \\
\hline
\end{tabular}

Table 3 Reaction free energies in solution (in kcal mol${ }^{-1}$ ) evaluated for the reduction of $\mathrm{Fe}(\mathrm{III})$ in the presence of different forms of the Al- $\mathrm{O}_{2}{ }^{\bullet}$ or $\mathrm{Al}-$ Citr $-\mathrm{O}_{2}{ }^{\bullet}$ complex. As a reference, the Fenton reaction in the absence of Al(III) is also included. $\Delta G_{\text {aq }}$ values computed at the levels of theory described in the Methodology section: B3LYP/TZ//B3LYP/DZ ( $\left.\Delta G_{\mathrm{aq}}^{\mathrm{B} 3 \mathrm{LP}}\right)$, wB97XD/TZ//B3LYP/DZ $\left(\Delta G_{\mathrm{aq}}^{\mathrm{B} 3, \mathrm{wB} B 7}\right), \mathrm{B} 3 \mathrm{LYP}-\mathrm{D} 3 / T Z / / B 3 L Y P-D 3 / D Z\left(\Delta G_{\mathrm{aq}}^{\mathrm{B} 3-D 3}\right)$ and wB97XD/ TZ//B3LYP-D3/DZ $\left(\Delta G_{\mathrm{aq}}^{\mathrm{B} 3-\mathrm{D} 3, w B 97}\right)$. Note that for clarity, the water molecules of the second solvation sphere are not included in the nomenclature

\begin{tabular}{|c|c|c|c|c|}
\hline & $\Delta G_{\mathrm{aq}}^{\mathrm{B} 3 \mathrm{LYP}}$ & $\Delta G_{\mathrm{aq}}^{\mathrm{B3}, \mathrm{wB} 97}$ & $\Delta G_{\mathrm{aq}}^{\mathrm{B} 3-\mathrm{D} 3}$ & $\Delta G_{\mathrm{aq}}^{\mathrm{B} 3-\mathrm{D} 3, \mathrm{wB} 97}$ \\
\hline $\begin{array}{l}\text { Absence of citrate and aluminum } \\
{\left[\mathrm{FeW}_{6}\right]^{3+}+\left[\mathrm{O}_{2}^{\bullet}\right]^{-} \rightarrow\left[\mathrm{FeW}_{6}\right]^{2+}+\mathrm{O}_{2}}\end{array}$ & -54.7 & -57.8 & -50.0 & -55.7 \\
\hline $\begin{array}{l}\text { Absence of citrate }{ }^{a} \\
{\left[\mathrm{FeW}_{6}\right]^{3+}+\left[\mathrm{AlW}_{5}\left(\mathrm{O}_{2} \bullet\right)\right]^{2+} \rightarrow\left[\mathrm{FeW}_{6}\right]^{2+}+\left[\mathrm{AlW}_{5}\left(\mathrm{O}_{2}\right)\right]^{3+}} \\
{\left[\mathrm{FeW}_{6}\right]^{3+}+\left[\mathrm{AlW}_{5}\left(\mathrm{O}_{2} \cdot\right]^{2+}+\mathrm{H}_{2} \mathrm{O} \rightarrow\left[\mathrm{FeW}_{6}\right]^{2+}+\left[\mathrm{AlW}_{6}\right]^{3+}+\mathrm{O}_{2}\right.} \\
{\left[\mathrm{FeW}_{6}\right]^{3+}+\left[\mathrm{AlOHW}_{4}\left(\mathrm{O}_{2}^{\bullet}\right)\right]^{+}+\mathrm{H}_{2} \mathrm{O} \rightarrow\left[\mathrm{FeW}_{6}\right]^{2+}+[\mathrm{AlOHW} 5]^{2+}+\mathrm{O}_{2}} \\
{\left[\mathrm{FeW}_{6}\right]^{3+}+\mathrm{Al}(\mathrm{OH})_{2} \mathrm{~W}_{3}\left(\mathrm{O}_{2}^{\bullet}\right)+\mathrm{H}_{2} \mathrm{O} \rightarrow\left[\mathrm{FeW}_{6}\right]^{2+}+\left[\mathrm{Al}(\mathrm{OH})_{2} \mathrm{~W}_{4}\right]^{+}+\mathrm{O}_{2}}\end{array}$ & $\begin{array}{r}-19.6 \\
-30.0 \\
-30.1 \\
-1.6\end{array}$ & $\begin{array}{r}-16.7 \\
-31.9 \\
-33.7 \\
-3.9\end{array}$ & $\begin{array}{r}-9.2 \\
-30.5 \\
-32.1 \\
-32.4\end{array}$ & $\begin{array}{l}-12.7 \\
-35.8 \\
-37.4 \\
-38.4\end{array}$ \\
\hline $\begin{array}{l}\text { Citrate interacting only with aluminum } \\
{\left[\mathrm{FeW}_{6}\right]^{3+}+\left[\mathrm{AlCitrW}_{2}\left(\mathrm{O}_{2}^{\bullet}\right)\right]^{2-} \rightarrow\left[\mathrm{FeW}_{6}\right]^{2+}+\left[\mathrm{AlCitrW}_{2}\left(\mathrm{O}_{2}\right)\right]^{-}} \\
{\left[\mathrm{FeW}_{6}\right]^{3+}+\left[\mathrm{AlCitrW}_{2}\left(\mathrm{O}_{2} \cdot\right)\right]^{2-}+\mathrm{H}_{2} \mathrm{O} \rightarrow\left[\mathrm{FeW}_{6}\right]^{2+}+\left[\mathrm{AlCitrW}_{3}\right]^{-}+\mathrm{O}_{2}} \\
\left.\left[\mathrm{FeW}_{6}\right]^{3+}+\left[\operatorname{AlCitr}(\mathrm{OH}) \mathrm{W}_{\left(\mathrm{O}_{2}\right.}\right)\right]^{3-}+\mathrm{H}_{2} \mathrm{O} \rightarrow\left[\mathrm{FeW}_{6}\right]^{2+}+\left[\mathrm{AlCitr}(\mathrm{OH}) \mathrm{W}_{2}\right]^{2-}+\mathrm{O}_{2}\end{array}$ & $\begin{array}{l}-10.2 \\
-37.9 \\
-40.6\end{array}$ & $\begin{array}{r}-4.8 \\
-30.6 \\
-31.8\end{array}$ & $\begin{array}{r}-4.9 \\
-36.1 \\
-36.5\end{array}$ & $\begin{array}{r}-2.6 \\
-41.2 \\
-42.1\end{array}$ \\
\hline $\begin{array}{l}\text { Citrate interacting only with iron } \\
{\left[\mathrm{FeCitrW}_{3}\right]^{-}+\left[\mathrm{AlW}_{5}\left(\mathrm{O}_{2}^{\bullet}\right)\right]^{2+} \rightarrow\left[\mathrm{FeCitrW}_{3}\right]^{2-}+\left[\mathrm{AlW}_{5}\left(\mathrm{O}_{2}\right)\right]^{3+}} \\
{\left[\mathrm{FeCitrW}_{3}\right]^{-}+\left[\mathrm{AlW}_{5}\left(\mathrm{O}_{2}^{\bullet}\right)\right]^{2+}+\mathrm{H}_{2} \mathrm{O} \rightarrow\left[\mathrm{FeCitrW}_{3}\right]^{2-}+\left[\mathrm{AlW}_{6}\right]^{3+}+\mathrm{O}_{2}} \\
{\left[\mathrm{FeCitrW}_{3}\right]^{-}+\left[\mathrm{Al}(\mathrm{OH}) \mathrm{W}_{4}\left(\mathrm{O}_{2}^{\bullet}\right)\right]^{+}+\mathrm{H}_{2} \mathrm{O} \rightarrow\left[\mathrm{FeCCitrW}_{3}\right]^{2-}+\left[\mathrm{Al}(\mathrm{OH}) \mathrm{W}_{5}\right]^{2+}+\mathrm{O}_{2}}\end{array}$ & $\begin{array}{l}28.2 \\
17.8 \\
17.7\end{array}$ & $\begin{array}{l}28.7 \\
26.0 \\
24.2\end{array}$ & $\begin{array}{l}34.0 \\
12.7 \\
11.1\end{array}$ & $\begin{array}{r}30.2 \\
7.0 \\
5.5\end{array}$ \\
\hline $\begin{array}{l}\text { Citrate interacting with both aluminum and iron } \\
{\left[\mathrm{FeCitrW}_{3}\right]^{-}+\left[\mathrm{AlCitrW}_{2}\left(\mathrm{O}_{2} \cdot\right)\right]^{2-} \rightarrow\left[\mathrm{FeCitrW}_{3}\right]^{2-}+\left[\mathrm{AlCitrW}_{2}\left(\mathrm{O}_{2}\right)\right]^{-}} \\
{\left[\mathrm{FeCitrW}_{3}\right]^{-+}+\left[\mathrm{AlCitrW}_{2}\left(\mathrm{O}_{2} \cdot\right)\right]^{2-}+\mathrm{H}_{2} \mathrm{O} \rightarrow\left[\mathrm{FeCitrW}_{3}\right]^{2-}+\left[\mathrm{AlCitrW}_{3}\right]^{-}+\mathrm{O}_{2}} \\
{\left[\mathrm{FeCitrW}_{3}\right]^{-}+\left[\mathrm{AlCitr}(\mathrm{OH}) \mathrm{W}\left(\mathrm{O}_{2} \cdot\right)\right]^{3-}+\mathrm{H}_{2} \mathrm{O} \rightarrow\left[\mathrm{FeCitrW}_{3}\right]^{2-}+\left[\mathrm{AlCitr}(\mathrm{OH}) \mathrm{W}_{2}\right]^{2-}+\mathrm{O}_{2}} \\
{ }^{a} \text { Data taken from ref. } 21 .\end{array}$ & $\begin{array}{r}37.7 \\
10.0 \\
7.3\end{array}$ & $\begin{array}{l}40.7 \\
14.9 \\
13.7\end{array}$ & $\begin{array}{r}38.3 \\
7.0 \\
6.6\end{array}$ & $\begin{array}{r}40.3 \\
1.7 \\
0.7\end{array}$ \\
\hline
\end{tabular}

(see Fig. 2). In addition, our previous calculations demonstrated the importance of including the second solvation sphere explicitly in order to obtain reliable solvation energies, ${ }^{44}$ therefore, ten water molecules were placed in the second coordination shell, mainly around the water/hydroxide molecules. All these structures are shown in Fig. 2 .

We found that the substitution of a water molecule by the superoxide radical anion is thermodynamically favorable in solution, when at least two water molecules are found in the first coordination shell. Thus, the formation of $\left[\operatorname{AlCitr}\left(\mathrm{H}_{2} \mathrm{O}\right)_{2}\right.$ $\left.\left(\mathrm{O}_{2}^{\bullet}\right)\left(\mathrm{H}_{2} \mathrm{O}\right)_{10}\right]^{2-}$ and $\left[\operatorname{AlCitr}\left(\mathrm{H}_{2} \mathrm{O}\right)(\mathrm{OH})\left(\mathrm{O}_{2}{ }^{\bullet}\right)\left(\mathrm{H}_{2} \mathrm{O}\right)_{10}\right]^{3-}$ shows $\Delta G_{\text {aq }}$ values of -4.0 and $-3.9 \mathrm{kcal} \mathrm{mol}^{-1}$, respectively. In contrast, the $\Delta G_{\mathrm{aq}}$ for the formation of $\left[\operatorname{AlCitr}(\mathrm{OH})_{2}\left(\mathrm{O}_{2}{ }^{\bullet}\right)\left(\mathrm{H}_{2} \mathrm{O}\right)_{10}\right]^{4-}$ is positive, $6.2 \mathrm{kcal} \mathrm{mol}^{-1}$. Thus, the amount of negatively charged groups in the first coordination shell influences the final stability of the aluminum-citrate-superoxide ternary complexes.

On the other hand, none of the substitutions of a hydroxide anion by the superoxide radical is thermodynamically favorable.
The formation of $\left[\operatorname{AlCitr}\left(\mathrm{H}_{2} \mathrm{O}\right)_{2}\left(\mathrm{O}_{2}{ }^{\bullet}\right)\left(\mathrm{H}_{2} \mathrm{O}\right)_{10}\right]^{2-}$ and $\left[\operatorname{AlCitr}\left(\mathrm{H}_{2} \mathrm{O}\right)(\mathrm{OH})-\right.$ $\left.\left(\mathrm{O}_{2}{ }^{\bullet}\right)\left(\mathrm{H}_{2} \mathrm{O}\right)_{10}\right]^{3-}$ species show values of 16.5 and $14.0 \mathrm{kcal} \mathrm{mol}^{-1}$, respectively. However, departing from the $\left[\operatorname{AlCitr}(\mathrm{OH})_{3}\left(\mathrm{H}_{2} \mathrm{O}\right)_{10}\right]^{4-}$ species, the formation of the $\left[\operatorname{AlCitr}(\mathrm{OH})_{2}\left(\mathrm{O}_{2}{ }^{\bullet}\right)\left(\mathrm{H}_{2} \mathrm{O}\right)_{10}\right]^{4-}$ complex is less endoergic, with a $\Delta G_{\text {aq }}$ value of $4.1 \mathrm{kcal} \mathrm{mol}^{-1}$.

In summary, as in the case of the absence of citrate, the interaction of the superoxide with aluminum can lead to a thermodynamically favorable species, with negative formation energies, only in the case of the substitution of water molecules in the first-coordination shell around aluminum, whereas the substitution of hydroxides is highly unfavorable. As expected, the presence of other negatively-charged groups in the firstcoordination shell of aluminum leads to the less favorable formation of an aluminum-superoxide complex, both in binary and ternary compounds. In this sense, the presence of citrate, with a total charge of $4-$, has a sizable effect on the substitution reactions. The addition of a more negative charge by the incorporation of a superoxide radical is energetically less 


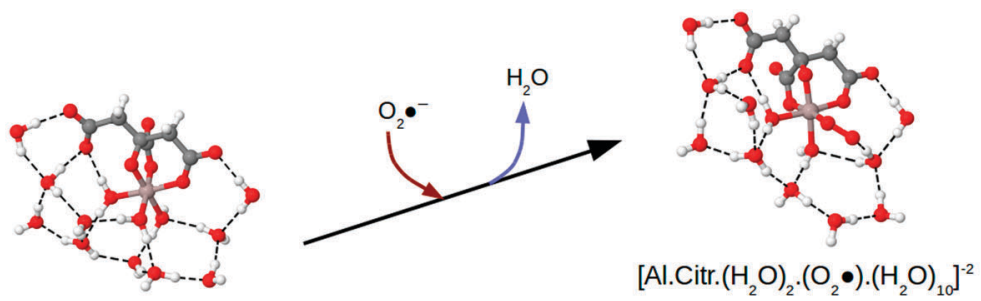

$$
\text { [Al.Citr. } \left.\left(\mathrm{H}_{2} \mathrm{O}\right)_{3} \cdot\left(\mathrm{H}_{2} \mathrm{O}\right)_{10}\right]^{-1}
$$
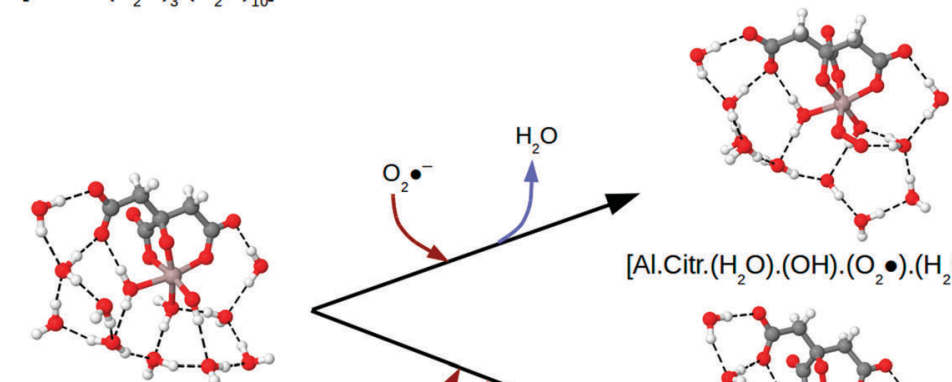

[Al.Citr. $\left.\left(\mathrm{H}_{2} \mathrm{O}\right)_{2} \cdot(\mathrm{OH}) \cdot\left(\mathrm{H}_{2} \mathrm{O}\right)_{10}\right]^{-2}$

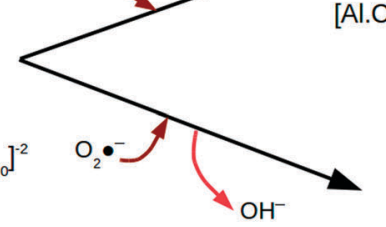

[Al.Citr. $\left.\left(\mathrm{H}_{2} \mathrm{O}\right) \cdot(\mathrm{OH}) \cdot\left(\mathrm{O}_{2} \bullet\right) \cdot\left(\mathrm{H}_{2} \mathrm{O}\right)_{10}\right]^{3}$
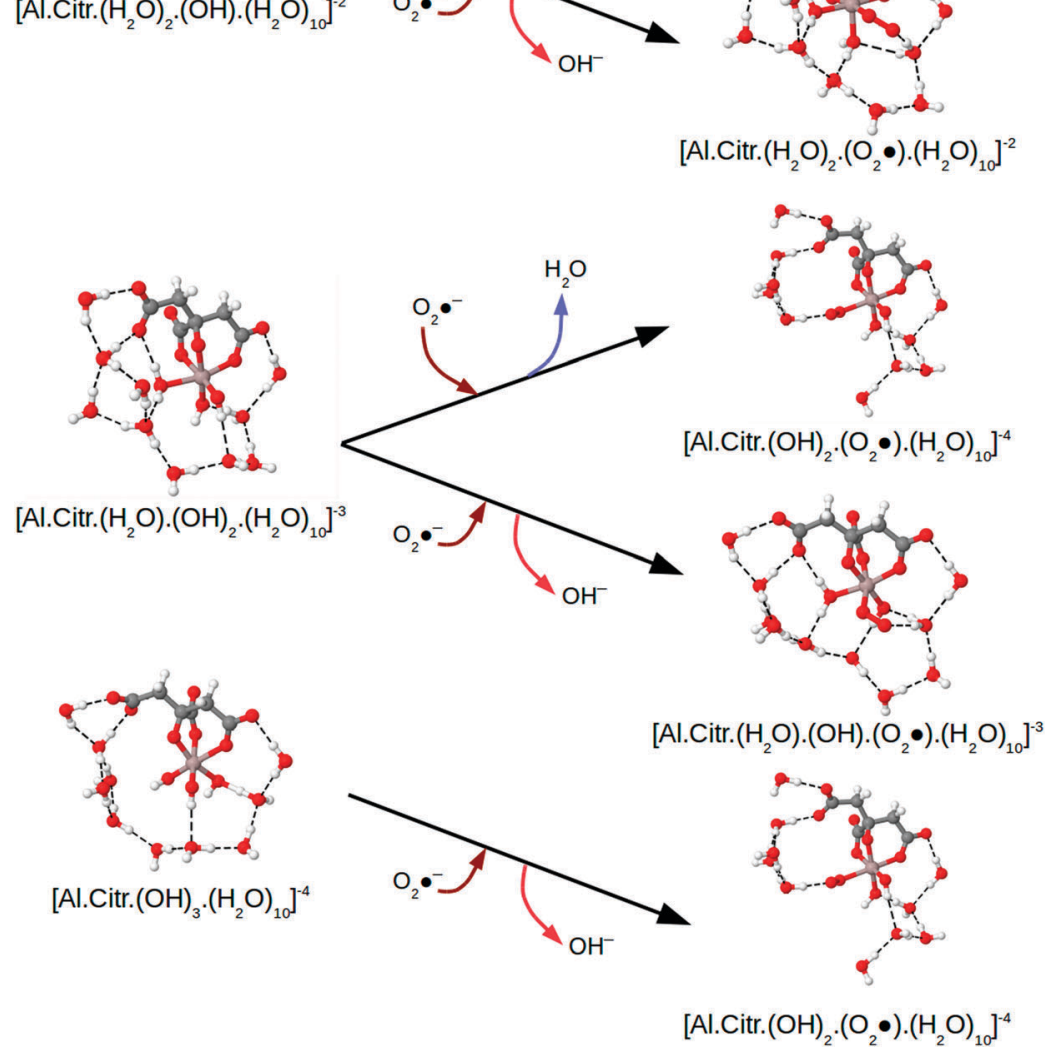

Fig. 2 Density functional theory structures optimized at the B3LYP/6-31++g(d,p) level of theory. On the left, initial Al-Citr complexes with different numbers of $\mathrm{H}_{2} \mathrm{O} / \mathrm{OH}$ molecules (according to eqn (1) and (2)). On the right, $\mathrm{Al}-\mathrm{Citr}-\mathrm{O}_{2}{ }^{\bullet}$ complexes formed by the substitution of either a $\mathrm{H}_{2} \mathrm{O}$ or a $\mathrm{OH}$ molecule by $\mathrm{O}_{2}$.

favorable than that in the absence of citrate. For instance, in the absence of citrate, the exchange of a water molecule with the superoxide shows a value of $\Delta G_{\mathrm{aq}}$ of $-19.5 \mathrm{kcal} \mathrm{mol}^{-1}$, while the same reaction in the presence of citrate shows a value of $-4.0 \mathrm{kcal} \mathrm{mol}{ }^{-1}$. However, although the binding of aluminum to citrate makes less favorable the interaction of the metal with the superoxide, the formation of a ternary aluminum-citratesuperoxide complex is still thermodynamically favorable, and therefore a ternary complex of this kind could also take part in the promotion of the Fenton reaction. In the next section, we evaluate how the inclusion of citrate influences the thermodynamics of the resultant redox reaction.

\section{Fenton reaction}

Previously, ${ }^{21}$ it was shown that an aluminum-superoxide complex could thermodynamically promote the Fenton reaction 
by reducing $\mathrm{Fe}(\mathrm{III})$ (sextuplet spin state) to $\mathrm{Fe}(\mathrm{II})$ (pentuplet spin state) through the following redox reaction:

$$
\mathrm{Fe}^{3+}+\left[\mathrm{AlO}_{2}^{\bullet}\right]^{2+} \rightarrow \mathrm{Fe}^{2+}+\mathrm{Al}^{3+}+\mathrm{O}_{2}
$$

As shown in Table 3, this reaction is thermodynamically favorable with a $\Delta G_{\text {aq }}$ value of $-30.5 \mathrm{kcal} \mathrm{mol}^{-1}$ when the superoxide is forming the $\left[\mathrm{AlO}_{2}{ }^{\bullet}\right]^{2+}$ complex, and the reaction is even more favorable with the $\left[\mathrm{Al}(\mathrm{OH}) \mathrm{O}_{2}{ }^{\bullet}\right]^{+}$and $\left[\mathrm{Al}(\mathrm{OH})_{2} \mathrm{O}_{2}{ }^{\bullet}\right]$ species, -32.1 and $-32.4 \mathrm{kcal} \mathrm{mol}^{-1}$, respectively. Note that the reaction is significantly less exothermic than when $\mathrm{O}_{2}{ }^{\bullet}$ does not interact with Al(III) (-50.0 kcal mol ${ }^{-1}$, see Table 3). Nevertheless, the formation of a stable $\mathrm{Al}(\mathrm{III})-\mathrm{O}_{2}{ }^{\bullet}$ complex may increase the lifetime of $\mathrm{O}_{2}{ }^{\bullet},{ }^{15}$ a very reactive species, which ultimately favors the Fenton reaction. ${ }^{20}$ Now, we analyze the effect in the thermodynamics of the redox reaction caused by the coordination of citrate to aluminum (Table 3 ).

Taking into account the most stable $\left[\mathrm{AlCitrO}_{2}{ }^{\circ}\right]$ ternary complex $\left(\left[\operatorname{AlCitr}\left(\mathrm{H}_{2} \mathrm{O}\right)_{2}\left(\mathrm{O}_{2}{ }^{\bullet}\right)\left(\mathrm{H}_{2} \mathrm{O}\right)_{10}\right]^{2-}\right)$ as a reference, the $\Delta G_{\text {aq }}$ value of reaction 7 is $-36.1 \mathrm{kcal} \mathrm{mol}^{-1}$, thus, it is $6 \mathrm{kcal} \mathrm{mol}^{-1}$ more stable than in the absence of citrate. A slightly larger exothermicity is gained $\left(\Delta G\right.$ value of $\left.-36.5 \mathrm{kcal} \mathrm{mol}^{-1}\right)$ when the $\left[\operatorname{AlCitr}\left(\mathrm{H}_{2} \mathrm{O}\right)(\mathrm{OH})\left(\mathrm{O}_{2}{ }^{\bullet}\right)\left(\mathrm{H}_{2} \mathrm{O}\right)_{10}\right]^{3-}$ complex is taken as the reference. Thus, the formation of a ternary aluminum-citratesuperoxide complex favors the redox reaction that reduces $\mathrm{Fe}(\mathrm{III})$ to $\mathrm{Fe}(\mathrm{II})$. In this sense, the presence of citrate would enhance the ability of aluminum to promote the Fenton reaction. The reason for this behavior is that the presence of a highly-negative charged citrate in the coordination shell of aluminum makes the loss of an electron in the superoxide, and therefore a reduction of its negative charge, more likely.

However, citrate is not only a good chelator for aluminum in biological systems, but also a good chelator of $\mathrm{Fe}(\mathrm{III})$. In fact, the binding free energy of citrate to $\mathrm{Fe}(\mathrm{III})$ is $-133 \mathrm{kcal} \mathrm{mol}^{-1}$, $10 \mathrm{kcal} \mathrm{mol}^{-1}$ more stable than the one for aluminum. Therefore, we also investigated the possibility of iron reduction with complexes in which iron is also chelated to citrate. We consider two possibilities: (i) reduction of $\mathrm{Fe}($ III)-citrate to $\mathrm{Fe}$ (II)-citrate by an aluminum-superoxide binary species and (ii) the reduction of $\mathrm{Fe}(\mathrm{III})$-citrate to $\mathrm{Fe}(\mathrm{II})$-citrate by an aluminumcitrate-superoxide ternary complex. In both cases and for all the complexes considered, the redox reaction is thermodynamically unfavorable. For instance, in the case that both iron and aluminum are chelated by citrate, the $\Delta G_{\text {aq }}$ value of the redox reaction 7 is $+7.0 \mathrm{kcal} \mathrm{mol}^{-1}$ when the $\left[\operatorname{AlCitr}\left(\mathrm{H}_{2} \mathrm{O}\right)_{2}\right.$ $\left.\left(\mathrm{O}_{2}^{\bullet}\right)\left(\mathrm{H}_{2} \mathrm{O}\right)_{10}\right]^{2-}$ complex is taken as the reference, and $+6.6 \mathrm{kcal} \mathrm{mol}^{-1}$ with $\left[\operatorname{AlCitr}\left(\mathrm{H}_{2} \mathrm{O}\right)(\mathrm{OH})\left(\mathrm{O}_{2}^{\bullet}\right)\left(\mathrm{H}_{2} \mathrm{O}\right)_{10}\right]^{3-}$. Therefore, the high stabilization of $\mathrm{Fe}(\mathrm{III})$ by citrate is a dominant factor with respect to the loss of an electron by the superoxide and stabilization of the aluminum-citrate complex. Thus, the chelation of iron by citrate has a protective effect with respect to the generation of $\mathrm{Fe}(\mathrm{II})$, and it promotes the Fenton reaction.

Overall, from our calculations, a complex picture emerges of the role of citrate in the thermodynamic promotion/inhibition of aluminum pro-oxidant activity, which is summarized in the scheme of Fig. 3. Aluminum hydrolytic species can form stable complexes with the superoxide, leading to stable binary aluminum-superoxide and ternary aluminum-citrate-superoxide complexes. Both types of complex have the ability to reduce $\mathrm{Fe}(\mathrm{III})$ to $\mathrm{Fe}$ (II) from a thermodynamic point of view. Moreover, the presence of citrate in ternary complexes promotes the loss of an electron from the superoxide, thus, increasing the iron-reduction ability of the aluminum ternary complexes with respect to the binary ones. However, if iron is also chelated to citrate, the possibility of iron reduction is compromised, leading in all cases to endothermic redox reactions. Finally, we should also take into account that in an excess of citrate and on formation of the $\left[\mathrm{Al}-\mathrm{Citr}_{2}\right]$ complex, in which all the coordination positions of aluminum are occupied by citrate, there would be no possibility of stabilization of superoxide by aluminum, and therefore, no possibility to reduce iron from the thermodynamic point of view.

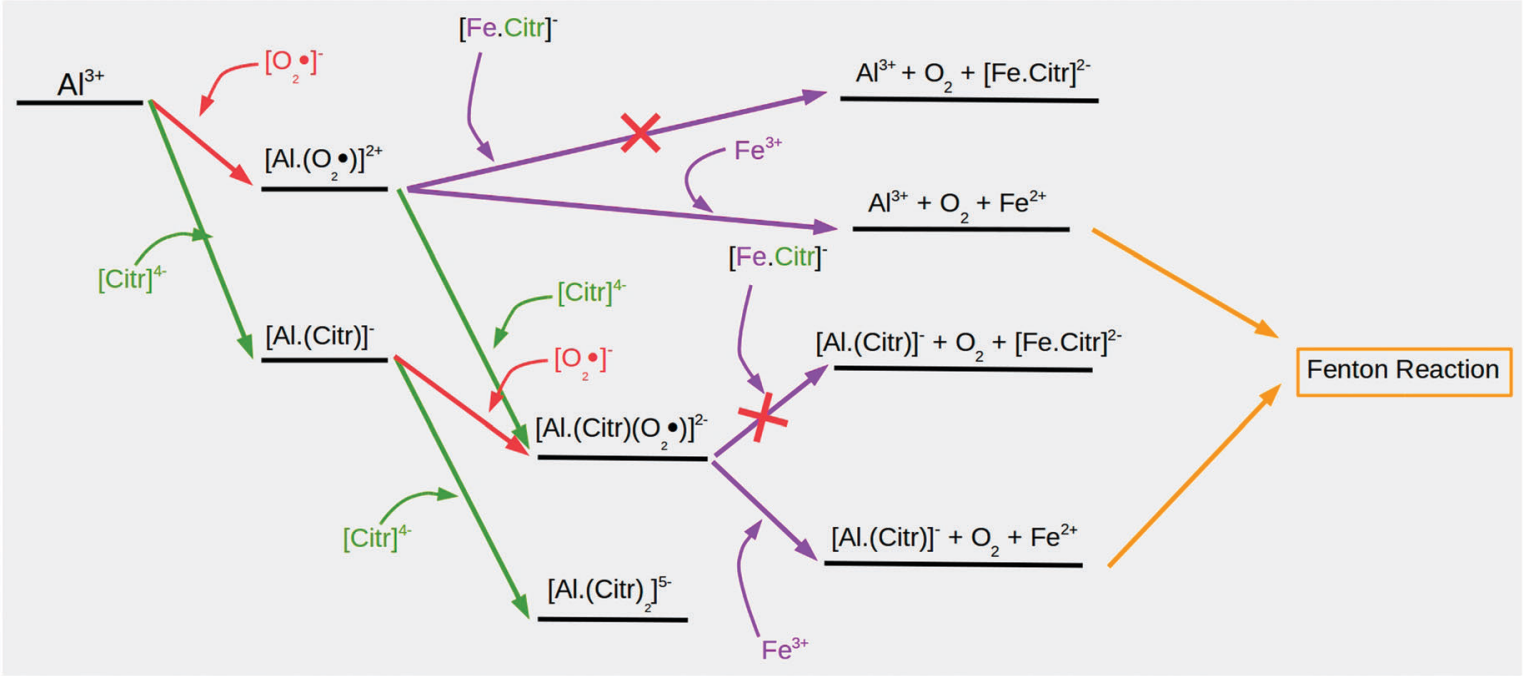

Fig. 3 Schematic representation of how citrate modulates the promotion of the Fenton reaction by Al(III). 
Therefore, a complex overall picture emerges from these calculations, in which depending on the type of complex formed (binary/ternary), and the relative concentrations of citrate/aluminum/iron, one could observe the promotion or inhibition of the pro-oxidant activity of aluminum. In addition, the reactions of oligonuclear and/or mixed hydroxo complexes of $\mathrm{Al}(\mathrm{III})$ can be extremely slow, resulting in long-lived nonequilibrium states of $\mathrm{Al}(\mathrm{III})$-ligand complexes, ${ }^{26,45}$ which, in the present context, could imply that aluminum could exert its pro-oxidant activity from the ternary species characterized in this work, even under conditions in which there is an excess of citrate.

\section{Delocalization indices and ligand affinity}

The effects of different functional groups considered herein (i.e. $\mathrm{H}_{2} \mathrm{O}, \mathrm{OH}^{-}, \mathrm{O}_{2}{ }^{-}$, and the alkoxide and carboxylate groups of citrate) on the Al-O interactions are analyzed by calculating the delocalization indices for all the $\mathrm{Al}-\mathrm{O}$ bonds in 17 structures: five aluminum hydrolytic species, five binary aluminum-superoxide complexes, four binary aluminum-citrate complexes and three ternary aluminum-superoxide-citrate complexes. Within each family of compounds, the complexes differ by the number of $\mathrm{H}_{2} \mathrm{O} / \mathrm{OH}^{-}$ligands in the first solvation shell of aluminum. Most of the structures correspond to hexacoordinated species, but there are also examples of structures penta $\left(\left[\mathrm{Al}\left(\mathrm{H}_{2} \mathrm{O}\right)_{2}(\mathrm{OH})_{3}\right]^{0}\right)$ and tetra-coordinated $\left(\left[\mathrm{Al}(\mathrm{OH})_{4}\right]^{-}\right)$. In all cases, the structures consider a double layer of explicit waters around aluminum, embedded in an implicit solvation model. The results are summarized in Fig. 4 and in Table 4.

Delocalization indices (DIs) are a measure of the degree of electron sharing between two atoms (see the Methodology section). Although Al-O bonds are mainly electrostatic in nature, there are also important dative interactions ${ }^{46}$ from the lone pair of the oxygens to the formally vacant $3 \mathrm{~s}$ and $3 p$ orbitals of $\mathrm{Al}(\mathrm{III})$. For functional groups/ligands of similar charge, like in the case of hydroxide, alkoxide, carboxylate and superoxide, the analysis of DIs can help in the rationalization of the specific aluminum-binding affinities of the different oxygen donors. Among the 17 structures analyzed, we find a consistent pattern with the DI decreasing in the following order: $\mathrm{Al}-\mathrm{OH}^{-}>\mathrm{Al}-\mathrm{CO}^{-}>\mathrm{Al}-\mathrm{COO}^{-}>\mathrm{Al}-\mathrm{O}_{2}{ }^{-}>\mathrm{Al}-\mathrm{H}_{2} \mathrm{O}$. There are several aspects to highlight in the following trends,

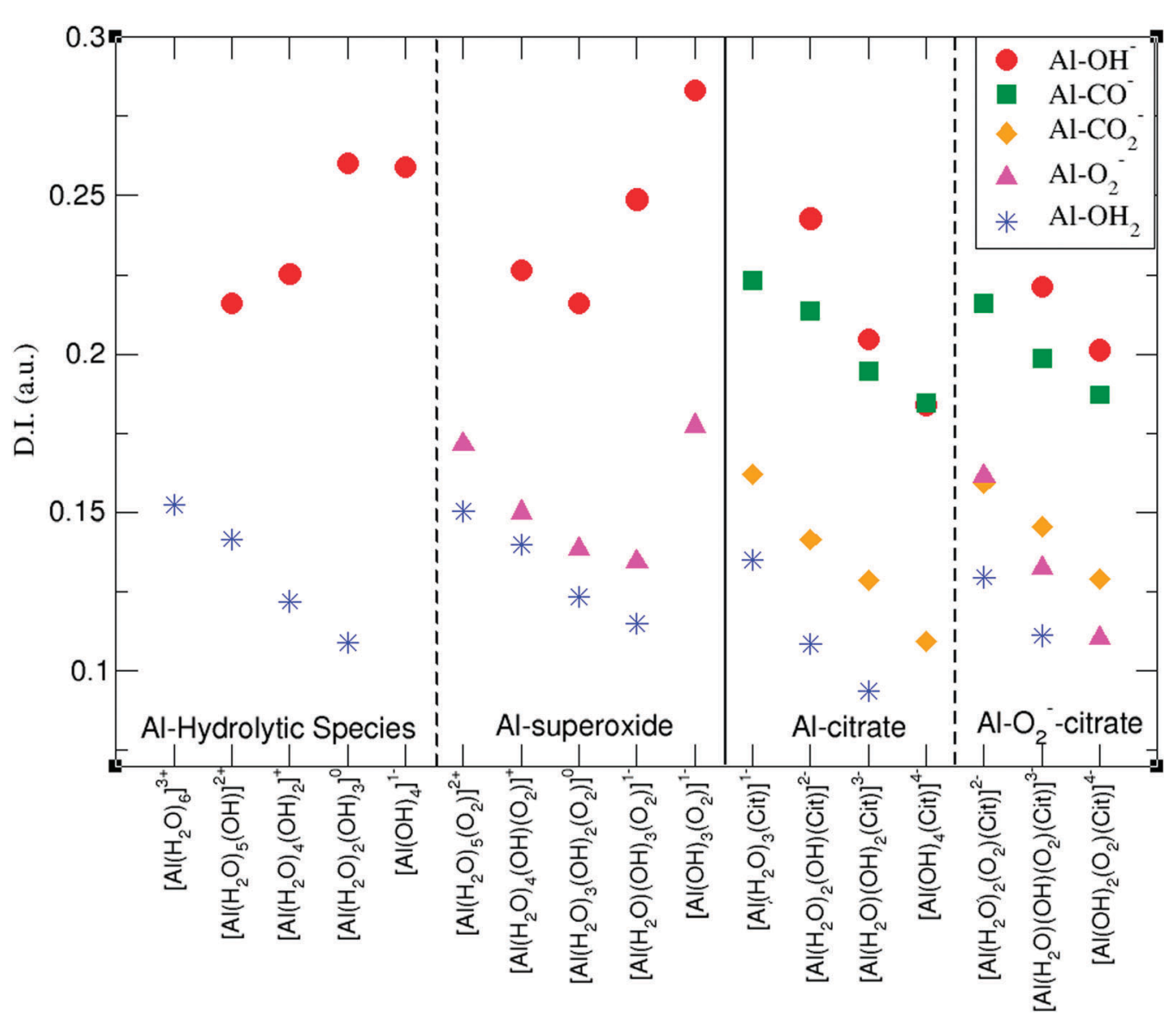

Fig. 4 The delocalization indices for the Al-O bonds of various aluminum hydrolytic species, aluminum-superoxide and aluminum-citrate binary complexes and ternary aluminum-superoxide-citrate complexes with different numbers of $\mathrm{H}_{2} \mathrm{O} / \mathrm{OH}$ filling the first-coordination shell of aluminum. The DIs are classified according to the different functional groups: hydroxide $\left(\mathrm{Al}-\mathrm{OH}^{-}\right)$, alkoxide $\left(\mathrm{Al}-\mathrm{CO}^{-}\right)$, acetate $\left(\mathrm{Al}-\mathrm{CO}_{2}{ }^{-}\right)$, superoxide $\left(\mathrm{Al}-\mathrm{O}_{2}{ }^{-}\right)$and water $\left(\mathrm{Al}-\mathrm{OH}_{2}\right)$. In the case where, for a given structure, several Al-O bonds with the same functional groups are present, the average value is provided in the figure. 
Table 4 Delocalization indices (in a.u.) obtained at the B3LYP/6-311++G(3df,2p) level of theory using the IEFPCM solvation model calculated for the Al-O interactions in aluminum complexes. The molecule of each oxygen atom is specified in parenthesis as: $\mathrm{W}$ : water $\left(\mathrm{O}^{\mathrm{H}} \mathrm{O}^{2}\right)$; $\mathrm{OH}$ : hydroxide $\left(\mathrm{O}^{\mathrm{OH}}\right)$; $\mathrm{SO}$ : superoxide $\left(\mathrm{O}^{\mathrm{O}_{2}}\right)^{\circ}$; $\mathrm{CA}$ : citrate alkoxide $\left(\mathrm{O}^{\mathrm{CO}}\right)$; $\mathrm{CCC}$ : citrate central carboxylate $\left(\mathrm{O}^{\mathrm{COO}}\right)_{\mathrm{c}}$; citrate terminal carboxylate $(\mathrm{CTC})\left(\mathrm{O}^{\mathrm{COO}} \mathrm{t}\right)$. The Mulliken spin densities computed at the same level of theory for the two oxygen atoms of $\mathrm{O}_{2}{ }^{\bullet}$ are also reported $\left(\rho_{\mathrm{O}_{2}} \cdot\right)$, $\rho_{\mathrm{O}_{2}}^{\mathrm{Al}}$. referring to the $\mathrm{O}$ atom interacting with $\mathrm{Al}(\mathrm{III})$

Aluminum hydrolytic species

\begin{tabular}{|c|c|c|c|c|c|c|}
\hline$\left[\mathrm{Al}\left(\mathrm{H}_{2} \mathrm{O}\right)_{6}\right]^{3+}$ & $0.1614(\mathrm{~W})$ & $0.1536(W)$ & $0.1383(W)$ & $0.1560(W)$ & $0.1507(W)$ & $0.1545(W)$ \\
\hline$\left[\mathrm{Al}\left(\mathrm{H}_{2} \mathrm{O}\right)_{5}(\mathrm{OH})\right]^{2+}$ & $0.1476(\mathrm{~W})$ & $0.1386(\mathrm{~W})$ & $0.1454(\mathrm{~W})$ & $0.1385(\mathrm{~W})$ & $0.1378(\mathrm{~W})$ & $0.2160(\mathrm{OH})$ \\
\hline$\left[\mathrm{Al}\left(\mathrm{H}_{2} \mathrm{O}\right)_{4}(\mathrm{OH})_{2}\right]^{+}$ & $0.1269(\mathrm{~W})$ & $0.1240(\mathrm{~W})$ & $0.1130(\mathrm{~W})$ & $0.1238(\mathrm{~W})$ & $0.2075(\mathrm{OH})$ & $0.2428(\mathrm{OH})$ \\
\hline$\left[\mathrm{Al}\left(\mathrm{H}_{2} \mathrm{O}\right)_{2}(\mathrm{OH})_{3}\right]^{0}$ & $0.1094(\mathrm{~W})$ & $0.1081(\mathrm{~W})$ & $0.2707(\mathrm{OH})$ & $0.2395(\mathrm{OH})$ & $0.2709(\mathrm{OH})$ & \\
\hline$\left[\mathrm{Al}(\mathrm{OH})_{4}\right]^{-}$ & $0.2693(\mathrm{OH})$ & $0.2694(\mathrm{OH})$ & $0.2393(\mathrm{OH})$ & $0.2583(\mathrm{OH})$ & & \\
\hline
\end{tabular}

Aluminum-superoxide complexes

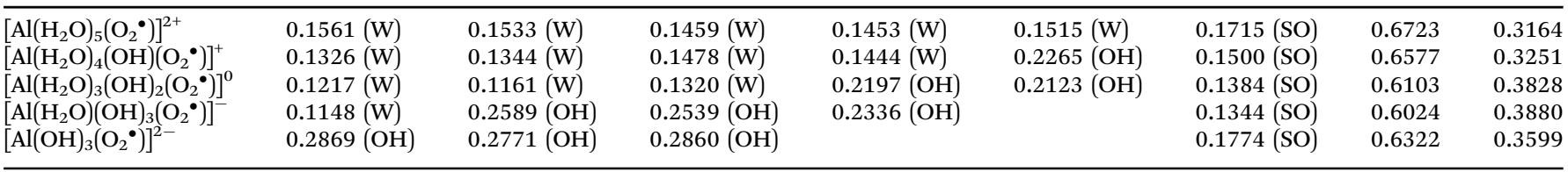

Aluminum-citrate complexes

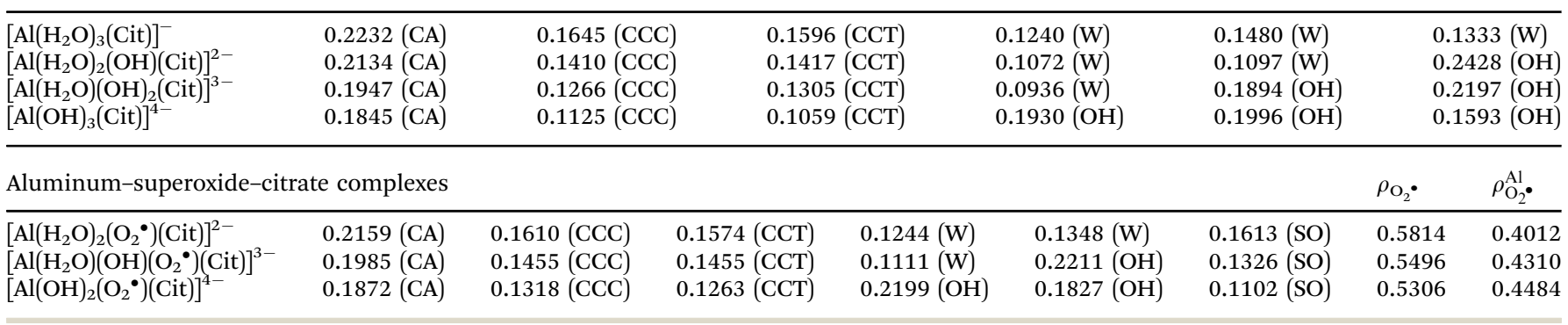

which allows for a clear rationalization of the ligand affinities described in the previous sections. The DI for $\mathrm{Al}-\mathrm{O}_{2}{ }^{-{ }^{-}}$bonds are the lowest among the charged ligands/groups but higher than that for water. This is in agreement with the favorable substitution of a water molecule by superoxide, and the unfavorable substitution of a charged ligand like hydroxide characterized in our previous work ${ }^{20}$ and shown in Table 1.

On the other hand, the highest Al-O delocalization indices correspond to the interaction of aluminum with hydroxides, with alkoxide having similar but smaller values. This is in agreement with the fact that hydrogen being less electronegative than carbon, makes $\mathrm{OH}^{-}$a better Lewis base than alkoxide. However, the DIs for carboxylate groups are substantially lower, due to the resonance of the $-\mathrm{COO}^{-}$moiety, which leads to a less dative oxygen. Finally, considering the superoxide, the higher electronegativity of oxygen compared to carbon and hydrogen makes $\mathrm{O}_{2}{ }^{-}$the poorest Lewis base among the charged functional groups/ligands of the present work.

We should also remark that the strong $\mathrm{Al}-\mathrm{OH}^{-}$interaction characterized in our structures is in agreement with the inherent stability of hydroxides at the first solvation layer around aluminum. ${ }^{47}$ Moreover, the presence of hydroxides has a sizable effect on the strength of the rest of the Al-O bonds with other ligands and functional groups, leading to a weakening of the rest of the Al-O bonds, and therefore, a lowering of their DIs. This is also in agreement with the known fact that the presence of hydroxides leads to a depleting of the toxicity of aluminum, by hindering the direct interaction of aluminum with bioligands. This leads to a low toxicity of aluminum at neutral $\mathrm{pH}$ values at the limit of chemical equilibrium, i.e., when all the aluminum is in the $[\mathrm{Al}(\mathrm{OH})]_{4}^{-}$form. However, as Exley et al. $^{26}$ has established, one should always bear in mind that non-equilibrium aluminum species could be highly relevant in the biological effects of this metal.

Finally, when we compare similar structures in the presence or in the absence of citrate, we encounter the fact that the presence of citrate leads consistently to lower DIs for aluminumsuperoxide bonds, in agreement with the lower affinity for superoxide displayed by aluminum-citrate complexes with respect to aluminum hydrolytic species. However, the DI of superoxide is still higher than the ones of water, and therefore the displacement of a water molecule by a $\mathrm{O}_{2}{ }^{--}$remains favorable. This decrease in aluminum-superoxide interaction in the presence of citrate also explains the fact that the aluminum-citrate-superoxide ternary complex is a better reductant than an aluminum-superoxide binary complex, since the loss of an electron and therefore the loss of an aluminumsuperoxide interaction is energetically less unfavorable for the former than for the latter.

Similar conclusions can be reached based on the analysis of the Mulliken spin densities $(\rho)$ at the two oxygen atoms of the $\mathrm{O}_{2}{ }^{\bullet}$ molecule. It should be pointed out that the spin densities computed based on the Mulliken atom partition are physically unsound, but they can be useful to determine qualitatively where the radical character is located and to describe trends in similar structures. The spin densities at the two oxygen atoms of $\mathrm{O}_{2}{ }^{\bullet}$ are shown in Table 4. For instance, the $\rho$ values at the two oxygen atoms of $\mathrm{O}_{2}{ }^{\bullet}$ in the $\left[\mathrm{Al}\left(\mathrm{H}_{2} \mathrm{O}\right)_{5}\left(\mathrm{O}_{2}{ }^{\bullet}\right)\right]^{2+}$ structure are 
0.6723 and 0.3164 . So, the sum of these two values is approximately 1 , but the spin density is mainly located at the $\mathrm{O}$ atom not interacting with $\mathrm{Al}(\mathrm{III})$. In other words, the molecule is highly polarized by the cation. However, the $\rho$ values computed on other structures show that: (1) the inclusion of $\mathrm{OH}^{-}$radicals in the $\mathrm{Al}(\mathrm{III})$ first coordination shell leads to a small but consistent decrease of the polarization, and (2) this effect is more effective when $\mathrm{Al}(\mathrm{III})$ interacts with citrate.

\section{Conclusions}

We have presented a thorough computational study on the influence of citrate, the main low-molecular-mass chelator of aluminum, on the pro-oxidant activity of this metal. We have found that from the thermodynamic point of view, stable ternary aluminum-citrate-superoxide complexes can be formed in aqueous solution, which can in turn promote the Fenton reaction by reducing $\mathrm{Fe}(\mathrm{III})$ to $\mathrm{Fe}(\mathrm{II})$. The presence of citrate has a two-fold effect: (i) it reduces the affinity of aluminum towards the superoxide, although it is still thermodynamically favorable to form aluminum-citrate-superoxide compounds, and (ii) thermodynamically, it favors the redox reaction in which iron is reduced from Fe(III) to Fe(II). However, we also found that citrate has a protective role in two ways: (i) if iron is linked to citrate, the Fe(III) oxidation state is highly stabilized, and the reduction of iron is no longer thermodynamically favorable, irrespective of whether we depart from an aluminum-superoxide binary complex or an aluminumsuperoxide-citrate ternary one; and (ii) in an excess of citrate, the formation of very stable 1:2 aluminum-citrate compounds is predicted to thermodynamically outcompete the formation of aluminum-superoxide-citrate complexes. In conclusion, we would like to remark that the use of delocalization indices, and in general of the QTAIM theory, is a powerful tool for the clear and full rationalization of the observed trends in complex stability, allowing us to establish an order of affinity of aluminum towards the different functional groups/ligands analyzed in the present work: $\mathrm{Al}-\mathrm{OH}^{-}>\mathrm{Al}-\mathrm{CO}^{-}>\mathrm{Al}-\mathrm{COO}^{-}>$ $\mathrm{Al}-\mathrm{O}_{2}{ }^{\bullet-}>\mathrm{Al}-\mathrm{H}_{2} \mathrm{O}$.

\section{Conflicts of interest}

There are no conflicts to declare.

\section{Acknowledgements}

Technical and human support was provided by SGI/IZO (SGIker) of UPV/EHU. Financial support comes from UPV/EHU (PES14/35), Eusko Jaurlaritza (IT588-13) and the Spanish Ministerio de Ciencia e Innovación (MINECO/FEDER) (CTQ2015-67608-P). G.D.T. acknowledges financial support from the European Commission, Horizon 2020 Research and Innovation Programme (grant agreement No. 642294 - TCCM).

\section{References}

1 C. Exley, J. Inorg. Biochem., 2003, 97, 1-7.

2 C. Exley, Trends Biochem. Sci., 2009, 34, 589-593.

3 J. Beardmore, X. Lopez, J. I. Mujika and C. Exley, Sci. Rep., 2016, 6, 30913.

4 Z. Rengel, Biometals, 2004, 17, 669-689.

5 C. Exley, Environ. Sci.: Processes Impacts, 2013, 15, 1807-1816.

6 L. Tomljenovic, J. Alzheimer's Dis., 2011, 23, 567-598.

7 R. A. Yokel, Curr. Inorg. Chem., 2012, 2, 54-63.

8 V. B. Gupta, S. Anitha, M. L. Hegde, L. Zecca, R. M. Garruto, R. Ravid, S. K. Shankar, R. Stein, P. Shanmugavelu and K. S. Jagannatha Rao, Cell. Mol. Life Sci., 2005, 62, 143-158.

9 G. Crisponi, V. Nurchi, V. Bertolasi, M. Remelli and G. Faa, Coord. Chem. Rev., 2011, 256, 89-104.

10 A. I. Arieff, Am. J. Kidney Dis., 1985, 6, 317-321.

11 A. C. Alfrey, G. R. LeGendre and W. D. Kaehny, N. Engl. J. Med., 1976, 294, 184-188.

12 J. I. Mujika, E. Rezabal, J. M. Mercero, F. Ruipérez, D. Costa, J. M. Ugalde and X. Lopez, Comput. Struct. Biotechnol. J., 2014, 9, e201403002.

13 S. Kong, S. Liochev and I. Fridovich, Free Radical Biol. Med., 1992, 13, 79-81.

14 A. Khan, J. P. Dobson and C. Exley, Free Radical Biol. Med., 2006, 40, 557-569.

15 C. Exley, Free Radical Biol. Med., 2004, 36, 380-387.

16 P. Zatta, T. Kiss, M. Suwalsky and G. Berthon, Coord. Chem. Rev., 2002, 228, 271-284.

17 S. Fukuzumi and K. Ohkubo, Chem. - Eur. J., 2000, 6, 4532-4535.

18 S. Fukuzumi, H. Ohtsu, K. Ohkubo, S. Itoh and H. Imahori, Coord. Chem. Rev., 2002, 226, 71-80.

19 S. Fukuzumi, J. Phys. Chem., 2002, 15, 448-460.

20 J. Mujika, F. Ruipérez, I. Infante, J. Ugalde, C. Exley and X. Lopez, J. Phys. Chem. A, 2011, 115, 6717-6723.

21 F. Ruipérez, J. Mujika, J. Ugalde, C. Exley and X. Lopez, J. Inorg. Biochem., 2012, 117, 118-123.

22 G. F. Van Landeghem, M. E. De Broe and P. C. D’Haese, Clin. Biochem., 1998, 31, 385-397.

23 A. Lakatos, F. Evanics, G. Dombi and R. Bertani, Eur. J. Inorg. Chem., 2001, 3079-3086.

24 R. Milacic, S. Murko and J. Scancar, J. Inorg. Biochem., 2009, 103, 1504-1513.

25 G. Berthon, Coord. Chem. Rev., 2002, 228, 319-341.

26 J. Beardmore and C. Exley, J. Inorg. Biochem., 2009, 103, 205-209.

27 J. Mujika, J. Ugalde and X. Lopez, J. Phys. Chem. B, 2014, 18, 1345-1349.

28 N. B. Luque, J. I. Mujika, E. Formoso and X. Lopez, RSC Adv., 2015, 5, 63874-63881.

29 A. Becke, J. Chem. Phys., 1993, 98, 5648-5652.

30 A. Becke, Phys. Rev. A: At., Mol., Opt. Phys., 1988, 38, 3098-3100.

31 C. Lee, W. Yang and R. G. Parr, Phys. Rev. B: Condens. Matter Mater. Phys., 1988, 37, 785-789.

32 S. Vosko, L. Wilk and M. Nusair, Can. J. Phys., 1980, 58, 1200-1211. 
33 S. Grimme, S. Ehrlich and L. Goerigk, J. Comput. Chem., 2011, 32, 1456-1465.

34 J. Tomasi, B. Mennucci and R. Cammi, Chem. Rev., 2005, 105, 2999-3093.

35 J. D. Chai and M. M. Head-Gordon, Phys. Chem. Chem. Phys., 2008, 10, 6615-6620.

36 M. J. Frisch, G. W. Trucks, H. B. Schlegel, G. E. Scuseria, M. A. Robb, J. R. Cheeseman, G. Scalmani, V. Barone, B. Mennucci, G. A. Petersson, H. Nakatsuji, M. Caricato, X. Li, H. P. Hratchian, A. F. Izmaylov, J. Bloino, G. Zheng, J. L. Sonnenberg, M. Hada, M. Ehara, K. Toyota, R. Fukuda, J. Hasegawa, M. Ishida, T. Nakajima, Y. Honda, O. Kitao, H. Nakai, T. Vreven, J. A. Montgomery, Jr., J. E. Peralta, F. Ogliaro, M. Bearpark, J. J. Heyd, E. Brothers, K. N. Kudin, V. N. Staroverov, R. Kobayashi, J. Normand, K. Raghavachari, A. Rendell, J. C. Burant, S. S. Iyengar, J. Tomasi, M. Cossi, N. Rega, J. M. Millam, M. Klene, J. E. Knox, J. B. Cross, V. Bakken, C. Adamo, J. Jaramillo, R. Gomperts, R. E. Stratmann, O. Yazyev, A. J. Austin, R. Cammi, C. Pomelli, J. W. Ochterski, R. L. Martin, K. Morokuma, V. G. Zakrzewski, G. A. Voth, P. Salvador, J. J. Dannenberg, S. Dapprich, A. D. Daniels, Ã Farkas, J. B. Foresman, J. V. Ortiz, J. Cioslowski and D. J. Fox, Gaussian09 Revision E.0 1, Gaussian Inc., Wallingford CT, 2009.

37 M. J. Frisch, G. W. Trucks, H. B. Schlegel, G. E. Scuseria, M. A. Robb, J. R. Cheeseman, G. Scalmani, V. Barone, G. A. Petersson, H. Nakatsuji, X. Li, M. Caricato, A. V. Marenich, J. Bloino, B. G. Janesko, R. Gomperts, B. Mennucci, H. P. Hratchian, J. V. Ortiz, A. F. Izmaylov, J. L. Sonnenberg, D. Williams-Young, F. Ding, F. Lipparini,
F. Egidi, J. Goings, B. Peng, A. Petrone, T. Henderson, D. Ranasinghe, V. G. Zakrzewski, J. Gao, N. Rega, G. Zheng, W. Liang, M. Hada, M. Ehara, K. Toyota, R. Fukuda, J. Hasegawa, M. Ishida, T. Nakajima, Y. Honda, O. Kitao, H. Nakai, T. Vreven, K. Throssell, J. A. Montgomery, Jr., J. E. Peralta, F. Ogliaro, M. J. Bearpark, J. J. Heyd, E. N. Brothers, K. N. Kudin, V. N. Staroverov, T. A. Keith, R. Kobayashi, J. Normand, K. Raghavachari, A. P. Rendell, J. C. Burant, S. S. Iyengar, J. Tomasi, M. Cossi, J. M. Millam, M. Klene, C. Adamo, R. Cammi, J. W. Ochterski, R. L. Martin, K. Morokuma, O. Farkas, J. B. Foresman and D. J. Fox, Gaussian16 Revision A.03, Gaussian Inc., Wallingford CT, 2009.

38 X. Fradera, M. A. Austen and R. F. W. Bader, J. Phys. Chem. A, 1999, 103, 304-314.

39 R. Bader and M. E. Stephens, J. Am. Chem. Soc., 1975, 97, 7391-7399.

40 K. Ruedenberg, Rev. Mod. Phys., 1962, 34, 326-376.

41 E. Matito, M. Solà, P. Salvador and M. Duran, Faraday Discuss., 2007, 135, 325-345.

42 T. A. Keith, AIMAll (Version 14.11.23), 2014.

43 J. I. Mujika, J. M. Ugalde and X. Lopez, Phys. Chem. Chem. Phys., 2012, 14, 12465-12475.

44 J. I. Mujika, J. M. Ugalde and X. Lopez, Theor. Chem. Acc., 2011, 128, 477-484.

45 J. Beardmore, G. Rugg and C. Exley, J. Inorg. Biochem., 2007, 101, 1187-1191.

46 A. E. Martell, R. D. Hancock, R. M. Smith and R. J. Motekaitis, Coord. Chem. Rev., 1996, 149, 311-328.

47 S. Bogatko, J. Moens and P. Geerlings, J. Phys. Chem. A, 2010, 114, 7791-7799. 